\title{
PEMETAAN BUDIDAYA BABI BALI DI BALI
}

\author{
PUTRI, T. I., N N. P. MARIANI, DAN A.W. PUGER \\ Fakultas Peternakan, Universitas Udayana \\ e-mail: tjokputrio807@gmail.com
}

\begin{abstract}
ABSTRAK
Penelitian bertujuan untuk mengetahui pemetaan budidaya babi bali di Bali. Penelitian dilaksanakan selama lima bulan mulai bulan Mei sampai dengan September 2016. Data ini sangat diperlukan untuk mengetahui pemetaan budidaya babi bali seperti pemberian pakan dan recording reproduksi ternak babi meliputi: umur awal pemeliharaan, umur pubertas, lama kebuntingan, bobot lahir, bobot sapih/umur sapih, calving interval dan jumlah anak per kelahiran di Kabupaten Tabanan, Gianyar, dan Bangli. Penelitian menggunakan metode survey dan penentuan responden menggunakan teknik purposive sampling dengan pertimbangan populasi babi bali tidak merata di semua kabupaten. Dari masing-masing kabupaten diambil 20 peternak sebagai responden. Data yang diperoleh dianalisis secara deskriptif sehingga mampu memberi gambaran yang akurat tentang budidaya babi bali di tiga kabupaten tersebut. Dari hasil pengamatan dapat disimpulkan bahwa tujuan pemeliharaan di Kabupaten Gianyar untuk bibit, Bangli dan Tabanan untuk bibit dan penggemukan. Sistem pemeliharaannya sama yaitu secara semi intensif, demikian juga jenis pakan yang diberikan yaitu limbah dapur, limbah kebun dan dedak padi. Data reproduksi di Kabupaten Gianyar, jumlah anak setiap kelahiran 9-12 ekor, bobot lahir 1-1,5 kg, disapih umur 60-90 hari, umur pubertas 6-8 bulan, jarak beranak (calving interval) 7 bulan.
\end{abstract}

Kata kunci: babi bali, pemetaan, budidaya

\section{MAPPING THE BALI PIGS FARMING IN BALI}

\begin{abstract}
This study aims to determine the mapping of the bali pigs farming in Bali. Research carried out for five months from May to September 2016. This data is needed to determine the mapping of the bali pigs farming (feeding, reproduction and recording include: rearing early age, the age of puberty, long gestation, birth weight, weaning weight/age, calving rearing and number of piglet per birth) in Tabanan, Gianyar and Bangli. This study use survey and to determine the respondents using purposive sampling technique with consideration of the bali pig population is not evenly across districts. From each district 20 farms taken as respondents. Data were analyzed descriptively so as to give an accurate picture of the balinesse pig farming in these three districts. From observation it can be concluded that the purpose of rearing bali pigs in three districts for breeding in Gianyar, for piglets and fattening in Bangli and Tabanan. Rearing system is same which is semi-intensive, as well as the type of feed given as of kitchen waste, garden waste and rice bran. Reproductive in Gianyar regency, the birth number of piglet every 9-12 head, 1-1.5 kg birth weight, weaning age of 60-90 days, 6-8 months of age puberty, birth spacing (calving interval) 7 months.
\end{abstract}

Keywords: bali pigs, mapping, breeding, piglet

\section{PENDAHULUAN}

Bali memiliki plasma nutfah ternak seperti babi bali, sapi bali, itik bali, kambing gembrong dan lailainnya. Babi bali merupakan salah satu plasma nuftah, keberadaan babi bali harus dilestarikan dan jangan sampai musnah.

Masyarakat Bali khususnya yang beragama Hindu yang hidup di pedesaan masih banyak memelihara babi bali, namun sudah banyak juga yang memelihara babi ras, diantaranya babi landrace, duroc, large white. Bali bali di Bali memiliki status sosial budaya yang sangat penting. Untuk kegiatan upacara dan bahan upakara banyak menggunakan daging babi. Babi bali secara genetik pertumbuhannya lebih lambat dibandingkan dengan babi ras. Babi bali memerlukan waktu 12 bulan untuk menca- 
pai berat badan $80 \mathrm{~kg}$, sedangkan babi ras 5-6 bulan.

Populasi babi bali terus menurun dan tidak merata di seluruh kabupaten. Budidaya ternak akan mempengaruhi produksi maupun populasi. Produksi ternak khususnya ternak babi sangat dipengaruhi oleh faktor genetik dan lingkungan. Sistem pemeliharaan babi bali di Bali sebagian besar masih tradisional/ diumbar dan diberi pakan seadanya, namun saat ini sudah banyak yang memelihara dengan sistem semi intensif. Babi bali dipelihara dalam kandang semi permanen, lantai diplester, dinding tembok batako, ada tempat pakan dan air minum, beratap genteng/seng. Jumlah babi yang dipelihara 5-10 ekor.

Keberhasilan usaha pemeliharaan babi bali lebih banyak ditentukan oleh pakan, baik secara kuantitatif maupun kualitatif. Hasil penelitian menunjukkan, $70 \%$ produktivitas ternak terutama pertumbuhan dan produksinya dipengaruhi oleh faktor lingkungan, sementara 30\% dipengaruhi oleh faktor genetik (Sihombing, 2016). Diantara faktor lingkungan tersebut, faktor pakan, kandungan nutrien, dan teknologi formulasi ransum berpengaruh paling besar yakni $60 \%$ dan menunjukaan faktor nutrisi cukup signifikan.

Berdasarkan hasil penelitian Budaarsa et al. (2013) didapatkan bahwa jenis hijauan yang diberikan oleh peternak babi di masing-masing kabupaten kota di Bali tidak banyak perbedaan yaitu: batang pisang, kangkung, ketela rambat, ketela pohon, daun pepaya, daun pisang dan hijauan lainnya, tapi yang dominan adalah batang pisang sekitar 95\%. Cara pemberian hijauan adalah bentuk segar dan direbus. Batang pisang kandungan utamanya adalah air, serat kasar dan mineral Zn (Hartadi, et al., 1990).

Sudiastra dan Budaarsa (2015) meneliti tentang studi ragam eksterior dan karakteristik reproduksi babi di tiga kabupaten yaitu Buleleng, Karangasem dan Klungkung. Dari penelitian tersebut diperoleh hasil dari eksteriornya babi bali ada dua yaitu warna hitam dan berwana hitam dengan belang putih pada perut dan keempat kakinya. Ciri khas babi bali yang utama perut melengkung ke bawah (lordosis). Panjang badan $97-137 \mathrm{~cm}$, kalau berbasis tulang $80-97 \mathrm{~cm}$, tinggi babi $49 \mathrm{~cm}$, dewasa kelamin 7-8 bulan, siklus birahi 15-20 hari, dikawinkan secara alami, jumlah anak 10-14 ekor sekali beranak.

Berdasarkan uraian di atas maka dilakukan penelitian tentang pemetaan babi bali di tiga kabupaten yaitu Tabanan, Gianyar, dan Bangli.

\section{METODE PENELITIAN}

Penelitian dilaksanakan selama 5 bulan mulai bulan Mei sampai September 2016. Kabupaten yang dipilih adalah Tabanan, Gianyar dan Bangli. Pemilihan kabupaten tersebut berdasarkan populasi babi bali di kabupaten tersebut paling tinggi dibandingkan dengan kabupaten lainnya. Dari masing masing kabupaten diambil 20 peternak sebagai responden.

Penelitian ini menggunakan metode survei dan penentuan responden menggunakan teknik purposive sampling dengan pertimbangan populasi babi bali di Bali tidak merata, hanya ada di beberapa kabupaten. Untuk memperoleh data tentang pemetaan budidaya babi bali yang di dalamnya termasuk bagaimana manajemen pemberian pakan dan recording reproduksi ternak babi meliputi: umur awal pemeliharaan, umur pubertas, lama kebuntingan, bobot lahir, bobot sapih/ umur sapih, calving interval dan jumlah anak per kelahiran (litter size).

Metode analisis yang digunakan dalam penelitian ini adalah dengan analisis deskriptif kualitatif.

\section{HASIL DAN PEMBAHASAN}

Pemetaan budidaya babi bali di provinsi Bali, diambil tiga kabupatan yaitu Kabupaten Tabanan, Gianyar dan Bangli. Berdasarkan hasil pengamatan di kabupaten Gianyar (kecamatan Tampaksiring) dari semua responden peternak babi yang dipelihara adalah untuk bibit. Bibit babi bali yang siap dipasarkan adalah babi yang telah disapih pada umur 6-8 minggu.

Sistem pemeliharan babi bali di kabupaten Gianyar yaitu secara semi intensif dengan kandang semi permanen, dinding tembok batako, lantai diplester, dan ada tempat pakan dan air minum, beratap genteng atau seng. Kebersihan lingkungan cukup bagus dan kandang dibersihkan 2 kali sehari.

Jenis pakan yang diberikan: limbah dapur, limbah kebun (batang pisang, daun ketela rambat, daun talas, "dagdag", dan lain-lainnya) dan dedak padi (Tabel 1). Pakan yang diberikan dalam bentuk basah, kering dan dimasak, diberikan 2 kali sehari dan air minumnya selalu tersedia.

Tabel 1. Jenis pakan yang diberikan

\begin{tabular}{llll}
\hline \multirow{2}{*}{$\begin{array}{c}\text { Pakan dan } \\
\text { Air Minum }\end{array}$} & \multicolumn{3}{c}{ Kabupaten } \\
\cline { 2 - 4 } Jenis pakan & Limbah dapur & Limbah dapur & \multicolumn{1}{c}{ Limbah dapur } \\
& Limbah kebun & Limbah kebun & Limbah kebun \\
& Batang pisang & Batang pisang & Batang pisang \\
& Daun ketela rambat & Daun ketela rambat & Daun ketela rambat \\
& Daun talas & Daun talas & Daun talas \\
Air minum & Dagdag & Dagdag & Dagdag \\
yang & Dedak padi & & Dedak padi \\
diberikan & & Ad libitum & Ad libitum \\
\hline
\end{tabular}

Data reproduksi antara lain jumlah anak babi setiap kelahiran 9-12 ekor, bobot lahir 1-1,5 kg, disapih umur 
60-90 hari, umur pubertas 6-8 bulan, jarak beranak (calving interval): 7 bulan (Tabel 2).

Tabel 2. Data reproduksi

\begin{tabular}{lccc}
\hline \multirow{2}{*}{ Data Reproduksi } & \multicolumn{3}{c}{ Kabupaten } \\
\cline { 2 - 4 } & Gianyar & Bangli & Tabanan \\
\hline Tujuan pemeliharaan & Bibit & Penggemukan & Penggemukan \\
Jumlah anak /kelahiran & $9-12$ ekor & - & - \\
Bobot lahir & $1-1,5 \mathrm{~kg}$ & - & - \\
Umur disapih & $60-90$ hari & - & - \\
Berat mulai dipelihara & - & $15-20 \mathrm{~kg}$ & $15-20 \mathrm{~kg}$ \\
Jarak beranak/ & 7 bulan & - & - \\
calving interval & & & - \\
Umur pubertas & $6-8$ bulan & - & $70-80 \mathrm{~kg}$ \\
Berat potong & - & $90-100 \mathrm{~kg}$ &
\end{tabular}

Pemeliharaan babi bali di Kabupaten Bangli (Kecamatan Sulahan) dari hasil wawancara dengan peternak tujuan pemeliharan sebagian besar untuk penggemukan dijual pada berat potong 90-100 $\mathrm{kg}$ (Tabel 2), tetapi ada pula yang memelihara induk babi untuk menghasilkan bibit. Anak-anak babi jantan yang sudah mencapai berat sapih dijual, sedangkan anak babi betina yang penampilan bagus dipelihara sebagai calon induk untuk nantinya digunakan sebagi pengganti induk babi yang sudah tua.

Sistem pemeliharaan dan jenis pakan yang diberikan hampir sama dengan di kabupaten Gianyar, hanya ada perbedaan dalam pemberian pakan yaitu ada yang memberikan dua kali dan ada yang memberikan satu kali dalam sehari. Jenis pakan yang diberikan: limbah dapur, limbah kebun (batang pisang, daun ketela rambat, daun talas, dagdag dan lain-lainnya), sedangkan pemberian dedak padi disesuaikan dengan kemampuan peternak (Tabel 1).

Di kabupaten Tabanan (Kecamatan Selemadeg Barat) tujuan pemeliharaan babi untuk penggemukan yang dipelihara mulai berat sapih $15-20 \mathrm{~kg}$ dan dijual pada berat potong kira-kira $70-80 \mathrm{~kg}$ (Tabel 2), sedangkan sistem pemeliharaannya secara semi intensif. Jenis pakan yang diberikan limbah dapur, limbah kebun (batang pisang, daun ketela rambat, daun talas, "dagdag", dan lain-lainnya) dan dedak padi (Tabel 1). Pakan yang diberikan dalam bentuk basah, kering dan dimasak, diberikan 2 kali sehari dan air minumnya selalu tersedia.

Secara umum masyarakat di tiga kabupaten yang beternak babi merupakan pekerjaan sambilan sehingga tujuan dari memelihara babi bali ini adalah untuk menunjang kegiatan upacara, tabungan dan untuk menambah penghasilan.

\section{SIMPULAN}

Dari hasil pengamatan dapat disimpulkan bahwa tujuan pemeliharaan di tiga kabupaten yaitu Gianyar untuk bibit, Bangli dan Tabanan untuk bibit dan penggemukan. Sistem pemeliharaannya adalah sama yaitu secara semi intensif, demikian juga jenis pakan yang diberikan yaitu limbah dapur, limbah kebun dan dedak padi. Data reproduksi di Kabupaten Gianyar, jumlah anak setiap kelahiran 9-12 ekor, bobot lahir 1-1,5 $\mathrm{kg}$, disapih umur 60-90 hari, umur pubertas 6-8 bulan, jarak beranak (calving interval) 7 bulan.

\section{UCAPAN TERIMAKASIH}

Pada kesempatan ini penulis mengucapkan banyak terimakasih kepada Rektor dan Ketua LPPM Universitaas Udayana, Denpasar atas dana yang diberikan melalui dana DIPA PNBP Unud (Hibah Unggulan Program Studi).

\section{DAFTAR PUSTAKA}

Bali dalam Angka. 2013. Badan Pusat Statistik Provinsi Bali. Penerbit BPS Provinsi Bali.

Budaarsa. K. N. Tirta. A, K. Mangku Budiasa dan P.A. Astawa. 2013. Hijuan Pakan Babi dan Cara Penggunaannya pada Peternakan Babi Tradisonal di Provinsi Bali. Disampaikan pada Seminar Nasional II Himpunan Ilmuwan Tumbuhan Pakan Indonesia (HIPTI) di Denpasar 28-29 Juni 2013.

Budaarsa. K. 2014. Potensi Ternak Babi dalam Menyumbangkan Daging di Bali. Makalah disampaikan pada Seminar Nasional Ternak Babi di Fakultas Peternakan Universitas Udayana, 5 Agustus 2014.

Budaarsa. K. 2002. Survei Kebutuhan Babi Guling di Kota Denpasar. Laporan Penelitian. DIK. Universitas Udayana.

Budaarsa. K. 2012. Babi Guling Bali dari Beternak Kuliner hingga Sesaji. Penerbit Buku Arti, Denpasar.

Hartadi,H., S Reksohadiprodjo dan A. D. Tillman. 1990. Tabel Komposisi Pakan untuk Indonesia. Yogyakarta, Gajah Mada University Press.

Sihombing, D.T.H. 2006. Ilmu Ternak Babi. Gadjah Mada University Press. Yogyakarta.

Sudiastra, I W. dan K. Budaarsa. 2015. Studi ragam eksterior dan karakteristik reproduksi babi bali. Majalah Ilmiah Peternakan. Vol.18, No.3, hal 100 - 105.

Sugiono. 2008. Metoda Penelitian Bisnis. Penerbit Alfabeta Bandung 